\title{
OS IMPACTOS JURÍDICOS DAS REFORMAS TRABALHISTAS E A (RE)MERCADORIZAÇÃO DO TRABALHO NAS EXPERIÊNCIAS INTERNACIONAIS
}

\section{The legal impacts of labor reforms and the (re) commodification of labor in international experiences}

Vitor Araújo Filgueiras (UNICAMP) Ilan Fonseca de Souza (Universidade Católica de Brasília)

Gabriela de Freitas Oliveira (UFBA)

Informações do artigo

Recebido em 04/12/2019

Aceito em 09/12/2019

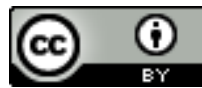

Esta obra está licenciada com uma Licença Creative Commons Atribuição 4.0 Internacional.

\section{Como ser citado (modelo ABNT)}

FILGUEIRAS, Vitor Araújo; SOUZA, Ilan Fonseca de; OLIVEIRA, Gabriela de Freitas. Os impactos jurídicos das reformas trabalhistas e a (re)mercadorização do trabalho nas experiências internacionais. Cadernos do

CEAS: Revista Crítica de Humanidades. Salvador, n.

248, set./dez., p. 514-543, 2019. DOI: https://doi.org/10.25247/2447-861X.2019.n248.p514-543

\begin{abstract}
Resumo
O objetivo deste texto é apesentar e debater o conteúdo e as consequências jurídicas da(s) reforma(s) trabalhista(s) em alguns países (Espanha, França, Alemanha, Reino Unido, México e Coreia) nas últimas décadas, comparando-os com o caso brasileiro após a implementação das leis n. 13.429/17 e 13.467/17. A despeito das particularidades de cada país, e das mudanças legais em cada um deles não serem unívocas, é possível identificar a tendência de redução da proteção ao trabalho em aspectos que vão da contratação à saúde e segurança. Ao redor do mundo, as reformas (re)mercadorizam o trabalho, associando a retirada de direitos trabalhistas ao aumento do poder de mando dos empregadores. A reforma trabalhista brasileira teve como um dos principais impactos o acesso à justiça do trabalho, consequência que repercute em outros direitos trabal histas. Os dados pesquisados evidenciam redução substancial na quantidade de ações trabal histas ajuizadas após reforma; no entanto, a dinâmica do mercado de trabalho e as estatísticas oficiais indicam que o suposto excesso de demandas decorre de um descumprimento sistemático às normas de regulação do trabalho. A reforma trabalhista brasileira, ao afastar os trabalhadores da justiça do trabalho, incentiva o descumprimento da legislação, reduzindo a efetividade dos direitos ainda existentes.
\end{abstract}

Palavras-chave: Direito do trabalho. Reformas. Acesso à justiça. Experiências internacionais. Mercadorização.

\section{Abstract}

The purpose of this paper is to present and discuss the content and legal consequences of labor reform(s) in some countries (Spain, France, Germany, the United Kingdom, Mexico and Korea) and to compare them with the Brazilian case after the implementation of Acts n. 13.429/17 and 13.467/17. Despite the particularities of each country, and the legal changes in each of them are not univocal, it is possible to identify the tendency to reduce labor protection in aspects ranging from hiring to health and safety. Around the world, reforms (re)commodify labor, linking the withdrawal of labor rights with increased employer power. One of the main impacts of the Brazilian labor reform was access to labor justice, a consequence that has repercussions on other labor rights. The surveyed data show a substantial reduction in the number of labor claims filed after retirement; however, labor market dynamics and official statistics indicate that the alleged over-demand results from a systematic failure to comply with labor regulation standards. The Brazilian labor reform, by pushing workers away from labor justice, encourages noncompliance with legislation, implying the low effectiveness of existing rights.

Keywords: Labor law. Reforms. Access to justice. International experiences. Commodification. 


\section{Introdução}

Nas últimas décadas, grandes alterações nas normas de proteção ao trabalho, popularizadas como reformas trabal histas, foram implementadas ao redor do mundo. Algumas reformas remetem aos anos 1980. Contudo, essas iniciativas se ampliaram nos anos 1990, 2000 e, especialmente, após a crise de 2008. A adoção de uma reforma trabal hista por um país tende a se relacionar com períodos de crise do emprego, já que o argumento fundamental apresentado pelos seus defensores é justamente o combate ao desemprego (FILGUEIRAS; LIMA; FONSECA, 2019).

O objetivo geral deste texto é apresentar e debater o conteúdo e as consequências jurídicas da implementação das chamadas Reformas Trabalhistas em sete países (Espanha, França, Alemanha, Reino Unido, México, Coréia do Sul e Brasil). Busca-se avaliar as modificações potenciais no direito material do trabalho - conjunto de normas gerais que criam direitos subjetivos com força cogente -, a possível redução da proteção material e os impactos nas instituições que regulam os direitos previstos. Especificamente, será discutida a relação entre as reformas trabal histas e a mercadorização do trabalho, analisando os mecanismos utilizados para promovê-la.

Embora a redução (eufemisticamente conhecida como flexibilização) dos direitos trabalhistas represente uma tendência geral, não se trata de um processo unívoco. Entre os países pesquisados, destaca-se o caso da Coreia do Sul como movimento contrário e que reforça a legislação de proteção ao trabalho.

A seleção dos seis países abordados, além do Brasil, se baseia na representatividade de suas reformas. As alterações legais adotadas nestes países têm evidência no cenário internacional, servindo como referência para os debates acadêmicos e para a definição de políticas públicas de outras regiões. Além disso, são países com características econômicas e tradições de regulação do trabalho heterogêneas. Partindo de realidades diversas, é possível apurar semelhanças e diferenças nos impactos das reformas. Isso permite que, dentro dos limites da razoabilidade, se generalizem as conclusões, sem que a análise seja superficial, ao contrário do que a compilação de uma quantidade maior de casos pode provocar.

Nesse sentido, o argumento principal aqui apresentadoé que as reformas, em geral, reduzem direitos dos trabal hadores de três formas: 1) supressão explícita de direitos, 2) eliminação de direitos via negociação, 3) fragilização da efetividade das normas restantes. Ao reduzirem a tela de proteção social e do trabalho, as reformas trabalhistas, em geral, buscam transpor a lógica do livre mercado para a relação de trabalho: enfraquecem contratos típicos e ampliam/criam modalidades atípicas de contratação. O norte das reformas é desafiar a impossibilidade da completa mercadorização do trabalho.

A pesquisa que deu origem a este texto analisou a legislação trabalhista dos sete países pesquisados, e fez um levantamento das alterações realizadas desde os anos 1980, quando aumenta 
a demanda por reformas. Foi realizada uma revisão de literatura sobre estas alterações legislativas e demais impactos do ponto de vistajurídico, particularmente quanto à efetividade e repercussões das alterações no campo do direito.

O artigo está dividido em três sessões, além desta introdução. Primeiro discutem-se as reformas trabalhistas em geral diante da tendência sistêmica do capitalismo de (re)mercadorizar o trabalho. A seguir, são apresentadas as principais alterações identificadas no direito material dos países pesquisados. As mudanças foram divididas nos seguintes eixos: formas de contratação, remuneração, tempo de trabalho e saúde e segurança do trabalho. Embora, por vezes, os eixos se interliguem e se confundam, foi realizado estudo no sentido de estabelecer uma separação geral. A sessão seguinte trata de aspectos relacionados à efetividade dos direitos, já que, mesmo sem qualquer modificação no direito material, eles podem deixar de existir no mundo real; nesta sessão, o foco fica sobre o acesso à justiça e a representação dos trabalhadores. Por fim, são apresentadas algumas considerações gerais sobre as tendências vigentes.

\section{Reformas trabalhistas e os limites de mercadorização do trabalho}

Ao contrário do que normalmente ocorre na literatura, a exemplo de Adascalitei e Morano (2015), consideramos como reforma trabal hista mudanças normativas que alteram profundamente a estrutura da regulação. Mudanças pontuais são constantes em quase todos os países, de modo que, considerá-las como reformas, seria pressupor que o mundo vive reformas permanentes. Além disso, o número de mudanças não significa, por si só, a ocorrência de uma reforma, já que uma única mudança na lei pode valer mais do que muitas mudanças somadas. Por fim, como a realidade não se desdobra diretamente da letra da lei, para que uma legislação provoque verdadeiro impacto, é necessário que ela seja efetiva.

Demandas a favor de mudanças legislativas na proteção ao trabalho remontam aos anos 1970, e se inserem num conjunto amplo de chamadas reformas que compõem a agenda neoliberal. Já nos anos 1980, países como Reino Unido e Espanha introduziram al terações em suas le istrabal histas. No Brasil, a partir dos anos 1990, houve muitas tentativas de reforma da CLT (Consolidação das Leis do Trabalho), contudo, a legislação não sofreu mudanças profundas nos anos 1990 e 2000, tendo sido mantida a estrutura da regulação do trabal ho no país (FILGUEIRAS, 2012; KREIN, 2007). Reformar a CLT permaneceu nos horizontes empresariais (ver, por exemplo, CNI, 1998, 2010, 2012) até que, em 2017, a reforma foi finalmente implementada, alterando profundamente a CLT.

O discurso a favor das reformas trabalhistas defende que é imperiosa a mode rnização do mercado de trabalho com a flexibilização das respectivas legislações. Todavia, essa dita "flexibilização" constitui, de fato, corte de direitos, pois a legislação trabalhista é, por definição, 
flexível. O texto normativo garante direitos mínimos, não impedindo negociações que visem melhorar as condições de trabalho. Sendo assim, aumentar a "flexibilização" só pode significar reduzir direitos existentes. Além disso, alguns direitos que já eram flexíveis, aplicando-se apenas a situações específicas, são eliminados pelas reformas laborais. Parte-se do pressuposto de que a redução ou o corte dos custos do trabalho estimulariam ou determinariam a contratação de trabalhadores pelos empresários.

Como Polanyi (2012) destaca, o mercado de trabalho impõe ao ser humano aquilo que o autor chama de "sanção natural da fome". Contudo, a completa mercadorização do trabalho enfrenta resistências da sociedade, estabelecendo-se uma regulação que limita as condições de compra e uso da força de trabalho pelo capital. Esses limites constituem a desmercantilização (ou desmercadorização) parcial da força de trabalho, que pode ocorrer tanto por meio do direito do trabal ho e das normas coletivas, como a partir da oferta de força de trabal ho. Neste artigo foc amos o direito do trabalho, sem desconhecer que a proteção ao trabalho, pelo lado da oferta, tem sofrido alterações importantes em vários países (como a restrição ao seguro-desemprego).

O direito do trabalho é um mecanismo que afasta o trabalho humano da lógica de funcionamento do mercado, ainda que de forma parcial - pois é formado por regras que são dependentes da reprodução do capital. Sendo assim, no que concerne à atuação estatal, o direito do trabalho regula a demanda por força de trabalho, para que o empregador respeite e cumpra determinadas regras independentemente das condições do mercado e da negociação entre oferta e procura, envolvendo capitalista e trabalhador. Essa impositividade (comumente chamada de irrenunciabilidade) se sobrepõe ao mercado, e, por isso, esse ramo do direito parcialmente desmercadoriza a força de trabalho. A desmercadorização é parcial porque, mesmo considerando uma situação em que o direito regule muitos aspectos do trabal ho assalariado, este continua sendo uma mercadoria submetida aos movimentos de acumulação de capital.

A "flexibilização" da legislação trabalhista ocorrida com as reformas ao redor do mundo não se deu de forma unívoca. Myant e Piasna (2017) destacam que, em alguns países, houve tentativas de compensar a precariedade de determinados tipos de contratos de trabalho por meio da criação de regulação protetiva específica. Mas, mesmo considerando as especificidades de cada país, a tendência, nos países pesquisados, tem sido em direção a mercados de trabalho com menor proteção ao trabalho. Portanto, há movimento no sentido de ampliar a mercadorização do trabalho em diversos países.

A atual onda de (re)mercadorização afeta diversos aspectos do direito do trabalho, questionando o próprio princípio de proteção, fundamental para este ramo do direito: ocorrem alterações no direito material, ou, de forma mais sutil, via quebra da sua efetividade. 


\section{Mudanças legislativas}

Um dos principais argumentos levantados a favor da adoção de reformas trabalhistas é que a legislação, excessivamente rígida e protetiva, supostamente representaria risco elevado para o empregador. Portanto, as reformas seriam imperativos para aumentar a segurança jurídica. No entanto, não se pode falar em segurançajurídica quando o tema é direito do trabalho nos países por nós pesquisados. Isto porque, vista como principal entrave ao desenvolvimento, a regulação trabalhista tem sido objeto de incessantes mudanças ao longo das três últimas décadas que implicaram, na maior parte dos casos, em redução de direitos. Em síntese, quem pretende segurança jurídica não deveria postular contínuas alterações legais.

Neste contexto, a mercadorização por nós aqui estudada é consequência da retirada de direitos associada ao aumento do poder dos empregadores. Além da eliminação explícita de direitos dos trabal hadores, sua efetividade tem diminuído, seja com restrição da atuação do poder público, seja como enfraquecimento dos sindicatos e da negociação coletiva.

As mudanças empreendidas pelas reformas laborais nos países estudados ocorreram na legislação ordinária (que exige prévia aprovação do parlamento, caso da Alemanha, México, Coreia e Brasil), extraordinária (como medidas provisórias ou ordonnances, caso do Brasil e da França), em atos do Poder Executivo (decretos) ou mesmo em artigos de Constituições. Agrupamos nos seguintes temas estas alterações: formas de contratação, remuneração, tempo de trabalho, saúde e segurança do trabalho, sindicatos e negociação coletiva, e acesso à justiça. Devemos ressaltar, desde logo, porém, o fato de que os institutos jurídicos por nós estudados são semelhantes em algumas nações, no entanto, em outras, não são totalmente correspondentes, de forma que o que temos aqui é uma aproximação para fins comparativos.

\section{Formas de contratação}

Contrato intermitente -on call work, contrato de zero hora

Inovação da reforma trabalhista brasileira de 2017, o contrato intermitente, também conhecido como contrato "zero hora", garante que o empregador pode ajustar o tempo de trabalho de acordo com sua demanda. A nova redação do $\$ 3^{\circ}$ do art. 443 da $C L T$ deixa claro que o contrato intermitente se adequa às demandas de cada setor, permitindo a prestação de serviço de forma descontínua, e limitando o pagamento salarial às horas efetivamente trabal hadas. É uma modalidade de contrato que pode ser aplicada indiscriminadamente, com exceção dos aeronautas.

$\mathrm{Na}$ Espanha, os contratos intermitentes são por prazo indeterminado com forma escrita, surgidos em 2001, e estão previstos no art. 16 do Estatuto de los Trabajadores (ET), autorizando sua utilização em atividades de cunho cíclico e com base em negociação coletiva. Na França, o contrato 
intermitente -obrigatoriamente por tempo indeterminado e com forma escrita -foi criado em 2000 com a edição da Lei Aubry II (art. 14). Sua utilização, porém, era restrita a alguns setores caracterizados por atividades sazonais e dependia de negociação coletiva; com a reforma de 20162017, a negociação pode permiti-lo independente de sazonalidade e, ao final de 2019, dispensará tais requisitos (Lei 1088-2016, art. 87). Conforme D’Amorim (2018), na Alemanha, o Arbeit Auf Abruf (contrato de plantão) foi criado através da "Lei de Promoção do Emprego" em 2003. Na segunda etapa da reforma trabalhista alemã, foi criada a possibilidade de um contrato com menos de 15 horas semanais. No Reino Unido, esta modalidade de contrato de trabalho foi permitida em 1996 (em 2015, foi proibida a imposição de exclusividade na prestação de serviços). No México, não há previsão expressa de trabal ho intermitente, no entanto, coma reforma (2012), há uma autorização implícita, pois o salário passou a poder ser fixado por unidade de tempo, e os contratos podem ter remuneração mínima de uma jornada diária de trabal ho (arts. 83 e 85).

\section{Terceirização-multi-partyemployment relationship (subcontracted labour)}

Trata-se de instituto jurídico que possui diversas nomenclaturas e conceitos variados nas legislações pesquisadas, alguns países referindo-se à terceirização como subcontratação e empreitada, outros como outsourcing. A terceirização é normal mente entendida como a transferência de parte do processo produtivo de uma empresa (contratante) para outra (contratada).

No Brasil, com a Lei n. 13.429/2017 a terceirização passou a ser autorizada tanto para atividades-meio quanto para atividades finalísticas. Na França, Alemanha, Reino Unido e Espanha, o regramento é semelhante por força da Diretiva n. 23/001 do Conselho da União Europeia, e a terceirização pode ocorrer tanto em atividades-meio quanto finalísticas, desde que a direção seja da empresa terceirizada. Em verdade, o conceito europeu aproxima-se muito mais da sucessão de empregadores do direito do trabalho no Brasil (art. $448 \mathrm{CLT}$ ). Nesses países não houve alterações substanciais recentes, diretamente concernentes aos parâmetros da terceirização (que foi incentivada por mudanças em outros aspectos do direito do trabalho).

Ainda assim, há nuances. Na Espanha, em 2006, o art. 42 do Estatuto de los Trabajadores foi alterado para permitir, em al guns casos, que a representação coletiva dos empregados terceirizados seja feita pelo sindicato dos empregados da empresa contratante; a Lei 32/2006 também impôs a responsabilidade do empreiteiro em observar normas de segurança e saúde do trabalho para terceirizados (VALVERDE, R, \& L, 2007). A reforma de 2012 autorizou que o acordo de empresa prevaleça sobre o setorial, não mais permanecendo a obrigação do empregador de remunerar igualmente empregados próprios e terceirizados (CAÑADA, 2018). Na França, a responsabilidade da tomadora dos serviços é subsidiária e a subcontratação é proibida em atividades que envolvam riscos industriais (MARCELINO, 2016). Na Alemanha, após o Plano Hartz I, foi autorizada a contratação de trabalhadores terceirizados para desempenho de atividades temporárias, mas a estes são garantidos 
os mesmos direitos dos empregados diretos (QUAGLIA, 2019). No México, a terceirização foi regulamentada e ampliada em 2012, nos artigos 15-A a D, da Ley Federal del Trabajo. As empresas podem utilizar contratos de terceirização em todas as atividades, desde que não sejam executadas por trabalhadores contratados diretamente. Ainda, o contrato de terceirização deve ser justificado por conta da natureza especializada do serviço e das suas qualificações técnicas específicas necessárias para a realização da atividade (LÓYZAGA DE LA CUEVA, 2013).

\section{Trabalho a tempo parcial-part-time work}

O trabalho em regime de tempo parcial caracteriza-se pela jornada de trabalho em tempo inferior à do contrato padrão. No Brasil, a partir da reforma de 2017, a contratação em regime de tempo parcial foi flexibilizada, possibilitando uma jornada semanal de até 30 horas semanais (anteriormente o limite era de 25 horas) sem a possibilidade de adição de horas extras. No entanto, se a jornada de trabal ho for estipulada em até 26 horas semanais, haverá possibilidade de realização de até 6 horas extraordinárias remuneradas com adicional de 50\%.

$\mathrm{Na}$ Espanha, a reforma trabalhista de 2012 flexibilizou o cumprimento de horas extras pelos trabalhadores a tempo parcial (CLAUWAERT \& SCHOMANN, 2012). Na França, o trabalho será a tempo parcial caso a jornada de trabalho seja inferior à do padrão legal de 35 horas. Em 2017, a reforma feita por Macron fixou que quatro temas só poderiam ser objeto de negociação por negociação coletiva ou acordo de setor expandido: definição do contrato, transição para tempo integral, igualdade de tratamento com funcionários e duração mínima; mas instituiu que todos os demais assuntos referentes ao trabalho a tempo parcial poderiam ser negociados via acordo de empresa. Assim, com a Lei El Khomri de 2017, as possibilidades de utilização do contrato de trabalho a tempo parcial foram ampliadas, autorizando a realização de horas extras e duração inferior a 24 horas semanais (ARAÚJO; DUTRA; JESUS, 2017). Na Alemanha, entende-se por trabal ho a tempo parcial aquele com jornada semanal inferior a 21 horas, não intermediado por uma agência de trabalho (EHMKE \& LINDNER, 2015). Ele se expressa principalmente por meio dos mini-jobs (até 15 horas semanais) ou dos mid-jobs (até 30 horas semanais). Apesar de serem modalidades de contratação a tempo parcial existentes desde 1971, se generalizaram a partir de 2003 com os Hart (EHMKE; \& LINDNER, 2015).

No Reino Unido, a legislação específica para os trabalhadores a tempo parcial é definida em The Fixed Term and Part-time Workers Regulations 2003: o direito para solicitar trabalho flexível, que anteriormente era limitado a funcionários que precisassem cuidar dos filhos, foi alargado, em 2014, a todos os empregados com pelo 26 semanas de emprego contínuo. Essa flexibilidade pode envolver alterações no número de horas, horários de trabalho ou local de trabalho (ILO, 2019). No México, conforme a Ley Federal del Trabajo, não há o contrato de trabal ho a tempo parcial como modalidade 
específica de contratação. Porém, pela leitura da LFT (arts. 61,69 e 83) o trabalho a tempo parcial é permitido, pois há pagamento do salário proporcional se ajornada é inferior à quantidade padrão de oito horas. Na Coreia, o trabalho a tempo parcial é uma modalidade de contrato de trabalho temporário, envolvendo jornada inferior a 40 horas semanais.

Trabalhoautônomo-disguisedemployment/dependente self-employment

O discurso a favor do empreendedorismo tem fortalecido a figura do trabal hador autônomo. O risco, usualmente assumido pelo empresário, é transferido para o trabal hador, que passa a ocupar a posição de "dono do seu próprio negócio".

A reforma brasileira de 2017, em seu artigo 442-B, retirou o requisito da continuidade e da exclusividade como elementos potencialmente caracterizadores do vínculo empregatício do autônomo. Na Espanha, antes de 2007 não havia disposição legal específica que previsse a figura do trabalhador autônomo, de forma que o seu conceito era inferido a partir da intepretação da noção de trabalhador subordinado e dependente. A Lei n. 20/2007, ou Estatuto del Trabajo Autónomo cobriu a lacuna, sistematizando e regulamentando a figura do trabalhador autônomo (RODRIGUEZ, 2016). Ainda, em 2007, foi criada a modalidade de trabalhador autônomo economicamente dependente, para regulamentar os trabalhadores que exerciam atividades laborais exclusivamente para um 'cliente' (BUSTILLO; ESTEVE, 2017). Assim, no caso espanhol há a figura dos trabajadores por cuenta propia, que seriam os trabalhadores autônomos em sentido estrito, exercendo sua atividade de acordo com os parâmetros típicos do trabalho autônomo e sem subordinação a terceiros (ALONSO, 2000) enquanto os trabajadores parasubordinados são aqueles que exercem trabalho autônomo economicamente dependente. Este tipo de trabalhador também tem a relação de trabalho regulamentada pela Lei n. 20/2007 que, no artigo 11, os define como trabalhadores que exercem atividade habitualmente para uma mesma pessoa física ou jurídica de quem dependem para receber, pelo menos, $75 \%$ de sua renda.

O governo francês tentou incentivar, em 2009, o empreendedorismo, por meio da criação de uma nova modalidade de trabalhador autônomo, o chamado "auto-empreendedor" (selfentrepeneur), com menos "burocracia" e sem impostos a serem pagos inicialmente. Desde 2009, na Alemanha, os trabalhadores autônomos precisam ter um seguro saúde obrigatório; enquanto que, desde 2006, podem contribuir para seu seguro-desemprego. Esta modalidade contratual - que tem crescido ano a ano - também pode esconder uma verdadeira relação de emprego (EHMKE \& LINDNER, 2015). No Reino Unido, uma política importante que incentivou o trabalho autônomo foi a Enterprise Allowance Scheme (LEAS) de 1983, que passou a oferecer apoio financeiro para quem quisesse iniciar seu próprio negócio, compensando parcialmente a perda do seguro-desemprego (COWLING \& MITCHELL, 1997). Desde então, têm ocorrido muitas modificações na legislação 
(tributação, agências etc.) que afetam lateralmente essa forma de contratação, mas não houve mudanças legais explícitas no conceito de autônomo (apenas a criação do worker - para subordinado que exerce trabalho autônomo economicamente dependente, aplicando-se a ele, parcialmente, a legislação trabalhista - que tem sido muito disputado nos tribunais (UNITED KINGDOM, 2015).

Trabalho temporário-temporaryagency work-ou por prazo determinado-fixed-term contract

No Brasil, o trabal ho temporário é regulado pela Lei n. 6.019/74 com as alterações legislativas da Lei n. 13.429/2017. Antes da reforma, o contrato de trabalho temporário tinha a duração máxima de 3 meses, e só poderia ser estendido com autorização do Ministério do Trabalho. Agora, o prazo para contratação do trabalhador temporário é de 180 dias, que podem ser prorrogados por mais 90 dias.

Na Espanha, a reforma trabalhista de 1984 permitiu que os contratos de trabal ho temporários (contratos temporales - mais assemelhados aos contratos por obra certa do Brasil) pudessem ser empregados em qualquer tipo de atividade, independentemente da natureza da função. A nova regulamentação de 2010 estabeleceu que estes contratos poderiam ser renovados de três em três meses, durante o período máximo de três anos. Quanto aos contratos de trabalho temporário propriamente ditos - com intermediação de uma empresa - a reforma de 2012 proibiu a renovação ilimitada de contratos temporários dentro do prazo de 24 meses (CLAUWAERT \& SCHOMANN, 2012). A reforma de 2010 também consagrou a diretiva 2008/104 da Comunidade Europeia, que prevê como direito dos trabalhadores temporários não apenas igualdade remuneratória, mas também igualdade nas condições essenciais do contrato, ao tempo em que autorizou o trabalho temporário em atividades perigosas, somente o vedandoem casos especiais. Além disso, as empresas de trabalho temporário foram autorizadas a atuar como agências de colocação.

Na França, o contrato de trabalho temporário, contrato provisório ou de missão (CTT) é regulamentado pela Lei $n^{\circ} 72-1$ de 3/1/1972. Os contratos de trabalho temporário foram impactados pela reforma trabalhista de 2017 (artigo L 1242-8 e seguintes), permitindo que uma negociação coletiva possa definir os seguintes aspectos: 1 ) a duração total do contrato; 2 ) o número máximo de renovações possíveis; 3 ) os métodos de cálculo do período de espera em caso de contratos sucessivos, e os casos em que este período não é aplicável. A referida reforma também estipulou que o descumprimento, por parte do empregador, da sua obrigação de enviar o contrato de trabalho temporário (CTT) no prazo máximo de 2 dias úteis após a contratação apenas enseja uma indenização novalor de um mês de salário.

Na Alemanha, desde os anos 1980 nota-se maior permissividade para o uso de contratos de trabalho por tempo determinado. Porém, apenas com as reformas do mercado de trabal ho que se iniciaram com o plano Hartz, foi autorizada a contratação de trabal hadores temporários por meio de 
agências (temporary agency contracts) (JAEHRLING, 2017). Até 2003, os contratos de trabalho temporários alemães tinham duração máxima de dois anos, sem possibilidade de prolongamento: a única forma possível de renovação seria por meio da contratação do trabalhador por tempo indeterminado (DAUDERSTÄDT, 2013; GASKARTH, 2014). A legislação foi alterada, permitindo que os contratos temporários fossem renovados até três vezes, desde que estas renovações ocorressem no período de dois anos. Poderiam, ainda, ser prorrogados por mais tempo, em caso de acordo coletivo. No entanto, após a flexibilização do mercado de trabal ho promovida pelos planos Hartz I-IV, este se tornou tão segmentado que, após 2010, em movimento contrário foram adotadas políticas e reformas que incentivaram a contratação de trabalhadores por tempo indeterminado. A remuneração dos trabal hadores temporários, contratados por meio de agência, foi equiparada à dos trabalhadores diretos - caso trabal hem no mesmo local por mais de nove meses, ou após 15 meses, em caso de acordo setorial. A duração máxima do contrato dos trabalhadores temporários de agências passou a ser de 18 meses, exceto em casos de acordos coletivos no setor (THEODOROPOULOU, 2018).

No Reino Unido, esta modalidade de contrato de trabalho é regulada pela diretiva da União Europeia sobre trabal hadores de agências ( $E U$ Agency Workers Directive, $A W D$ ), que foi concebida em 2002 e adotada em 2008 (FORDE \& SLATER, 2016): em linhas gerais, os trabalhadores temporários possuem os mesmos direitos dos diretamente contratados pelo empregador. No México, o contrato de trabalho temporário (trabajos de temporada) poderá ser empregado no caso de atividades fixas (não eventuais) e periódicas, mas de natureza descontínua, no caso de atividades sazonais, ou que não requeiram a prestação de serviços durante a semana, mês ou ano (art. 39-F da Ley Federal del Trabajo). Assim, os contratos de trabalho por temporada podem ser utilizados em casos que não exijam prestação de serviço contínua. Apenas a partir da reforma, em 2012, esse tipo de contrato foi regulamentado, com igualdade de direitos em relação aos trabalhadores por tempo indeterminado.

Como se vê, no Brasil, aspectos da legislação trabalhistas como terceirização, trabalho parcial, temporário/prazo determinado, intermitente e trabalho autônomo vêm coincidindo com a tendência mundial de liberação ou ampliação.

Uma exceção a esse cenário tem ocorrido nos últimos anos na Coreia, que, mesmo sem alterações legislativas recentes sobre contratação, têm ocorrido mudanças no sentido oposto ao verificado nos demais países, particularmente com a inciativa do governo de eliminar as formas de contratação precária no serviço público (HEE, 2019).

\section{Remuneração}

Quanto a este tópico, buscamos identificar alterações nas reformas trabalhistas dos países envolvidos relacionadas à remuneração do salário mínimo e à forma de pagamento das horas 
extraordinárias. A tendência verificada-com exceção da Alemanha, Reino Unido e Coreia-tem sido no sentido de cortar parcelas salariais ou reduzirdiretamente o salário.

Salários eflexibilidade: salário mínimo e remuneração das horas extraordinárias

A reforma trabalhista brasileira não retirou explicitamente direitos previstos no artigo $7^{\circ} \mathrm{da}$ Constituição Federal. Mas assim o fez indiretamente, ao criar instrumentos que esvaziam o conteúdo do direito e inviabilizam seu acesso pelos trabalhadores. Ao aumentar a flexibilidade da remuneração, a lei n. 13.467/2017 retirou a natureza salarial de diárias de viagens, ajudas de custoe abonos (art. 457, $\left.\int 2^{\circ}\right)$. A habitualidade deixou de ser elemento fundamental para definir o que terá ou não natureza salarial. Assim, por exemplo, o vale-alimentação não tem mais natureza salarial, a menos que seja pago em dinheiro. Ainda, as horas in itinere - tempo de deslocamento do trabalhador da sua residência ao local de trabal ho e retorno em locais não servidos por transporte público - deixaram de ser consideradas tempoà disposição do empregador e não precisam mais ser remuneradas. A reforma também autorizou o acréscimo de até duas horas extras na jornada de trabalho, não mais apenas por convenção coletiva e acordo coletivo de trabalho, mas por acordo individual (art. 59 da CLT). O limite de dez horas diárias de trabalho pode alcançar uma jornada de 12 horas diárias mediante acordo individual escrito, se houver descanso ininterrupto por 36 horas seguintes (art. 59-A) sem acréscimo remuneratório. Além disso, a jornada prorrogada pelo regime de compensação - dispensando o pagamento das horas extraordinárias - permite que seja extrapolado o limite de 44 horas semanais de trabalho por acordo individual (caso a compensação ocorra no mesmo mês).

Na Espanha, uma alteração relevante consistiu no aumento da indenização devida em caso de dispensa do trabalho, passando de 8 dias de salário por ano de serviço trabal hado, para 12 dias de remuneração para cada ano completo (art. 49, 1, c do Estatuto de los Trabajadores). Houve, concomitantemente, um conjunto de alterações (indenizações rescisórias, extensão de horas extras não pagas e congelamento do salário mínimo) que reduziram as remunerações dos trabalhadores. As horas extraordinárias na Espanha podem ser compensadas com descanso em caso de acordo individual ou coletivo. Um trabalhador não pode realizar mais do que 80 horas extras por ano, e estas devem ser realizadas voluntariamente pelo trabalhador (ANXO \& KARLSSON, 2019). No entanto, o limite de 80 horas anuais não se aplica caso as horas extras tenham sido necessárias para prevenir ou reparar danos extraordinários ou urgentes, sendo que o trabalhador é obrigado a realizá-las. Em 2012, os acordos por empresa passaram a prevalecer frente a acordos setoriais sobre pagamento ou compensação de horas extras.

Na França, conforme lei El Khomri (2016), as horas suplementares têm acréscimo de $25 \%$ nas 8 primeiras horas e 50\% depois deste período ( $L$ 3121-22), contudo, existe a possibilidade de derrogação desta regra mediante acordo por empresa ou convenção coletiva, desde que respeitado 
o piso de 10\% de acréscimo à hora extra trabalhada (ARAÚJO; DUTRA; JESUS, 2017). Ainda na França (2016-2017), instituiu-se que, na ausência de acordo de empresa ou convenção coletiva, o contrato de trabalho também pode fixar a remuneração do tempo de pausa, impactando também na remuneração dos trabalhadores.

Na Alemanha, o salário mínimo foi estabelecido pela primeira vez em 2015, ao nível de 8,5 euros por hora. Foi estabelecida uma comissão que, assim como no Reino Unido, é responsável por sugerir, periodicamente, reajustes ao salário mínimo. O primeiro reajuste salarial ocorreu em junho de 2016, alcançando o nível de 8,84 euros por hora. No Reino Unido, o salário mínimo foi desregulamentado em 1993, com o incentivo à remuneração flexível. Em 1998, voltou a ser regulamentado pelo National Minimum Wage Act 1998 e pelo National Minimum Wage Regulations 2015. O salário mínimo é revisto anualmente pelo parlamento, baseado nas recomendações da Low Pay Commission (LPC). Neste país, os empregadores não precisam, necessariamente, remunerar as horas extras com percentual extraordinário. A única limitação é que a remuneração por hora do trabalhador não pode ser abaixo do salário mínimo nacional (UNITED KINGDOM GOVERNMENT, 2019).

No México, a reforma trabal hista criou a figura do trabalhador polivalente, permitindoque os trabalhadores executem tarefas conexas ou complementares à atividade principal caso recebam compensação salarial correspondente. A legislação pouco esclarece o que seriam atividades conexas ou complementares, deixando ao poder discricionário do empregador defini-las, flexibilizando também, assim, o salário dos trabalhadores (LÓYZAGA DE LA CUEVA, 2013). Com isso, a remuneração por desvio de função ou acréscimo de função - tal como ocorre no Brasil - deixa de existir. No México, porém, não houve alteração recente em matéria de horas extraordinárias: no entanto, o trabalho das domésticas foi regulamentado prevendo horas a mais para descanso em sua jornada diária, no art. 333 da LFT, o que impacta em maior remuneração de horas extraordinárias para esta categoria caso seja desrespeitado tal descanso.

Na Coreia, a Lei de Padrões Trabalhistas classifica o salário em normal (ou base) e salário médio (este utilizado para cálculo do aviso prévio, aposentadoria e pagamentos extras). $O$ salário mínimo é fixado anualmente pelo Ministério do Trabalho por lei: se inferior ao mínimo legal, será considerado automaticamente inválido (art. $6^{\circ}$ da Lei do Salário Mínimo). Trabalhadores com menos de 3 meses de admissão podem sofrer redução de $10 \%$ no salário mínimo. O adicional de hora extraordinária é de 50\% sobre o salário base (EMBAIXADA DO BRASIL EM SEUL, 2019). Neste país, a partir de 2017, o salário mínimo passou a experimentar forte crescimento (mais de $25 \%$ em 2 anos).

Tempo de trabalho 
A tendência, nos países pesquisados, tem sido no sentido de deixar para o empregador a decisão sobre como distribuir a jornada de trabalho, permitindo o aumento de jornada ou redução de descanso.

\section{Jornada de Trabalho}

No Brasil, foram adotados diversos dispositivos que estimulam o aumento da duração do trabalho além do limite semanal de 44 horas previsto na Constituição Federal. Isso ocorre através da regulação do banco de horas, da eliminação das horas in itinere enquanto componentes da jornada de trabalho, e da possibilidade de prolongamento dajornada de trabalho em local insalubre (art. 611-A da (LT). A lei n. 13.467/2017 autoriza, no artigo 59, que o banco de horas seja pactuado por acordo individual escrito, desde que a compensação das horas ocorra no prazo máximo de seis meses.

$\mathrm{Na}$ Espanha, o tempo de trabalho é regulamentado por leis, mas alguns aspectos, como a jornada diária de trabalho, podem sernegociados. A legislação estabelece que a jornada de trabalho semanal deve ser, em média, igual a 40 horas, considerando-se o período de um ano. Com a reforma ocorrida em 2010, a redução de jornada de trabalho foi prevista, juntamente com a suspensão do contrato que já existia, após consulta aos trabal hadores e autorização da autoridade estatal, como forma de atender aos interesses empresariais que, por motivos técnicos, econômicos ou de organização da produção, necessitem de redução de custos (art. 47, 2 do Estatuto de los Trabajadores), Em 2012, a reforma voltou a alterar o artigo 34 do Estatuto e agora permite negociação da jornada por acordos de empresa (RDL 03/2012). Neste país, a reforma laboral ocorrida em 2012 também autoriza que acordos de empresa prevaleçam sobre convenções coletivas (acordos setoriais) em matérias envolvendo pagamento ou compensação de horas extras e a remuneração específica do trabalho por turnos (art. 84, 2, "b", doET).

Na França, a jornada legal de trabalho é de 35 horas em todos os setores da atividade econômica e, conforme artigo 3121-1, do Código de Trabalho, a jornada de trabalho é calculada de acordo com o tempo de trabalho efetivo, e este vem a ser o tempo do empregado à disposição do patrão. Em 2008, a lei n. 2008-789 autorizoua realização de ajustesnajornada de trabal ho mediante convenção coletiva. A lei El Khomri de 2017, por sua vez, estabeleceu a possibilidade de ampliação através de um acordo de empresa da jornada de trabalho semanal. Neste país, o banco de horas, denominado de cadre de décompte é legalmente permitido. Em geral, as horas extraordinárias trabalhadas são contabilizadas semanalmente, para fins de pagamento de adicionais, mas, para fins de cumulação com uma compensação em descanso, apenas as horas extras trabal hadas além da cota anual entram no cálculo (MINISTÈRE DU TRAVAIL, 2019).

Na Alemanha, normalmente, a jornada de trabalho é estabelecida por convenções coletivas, mas a legislação alemã estabelece padrões gerais. Assim, a jornada de trabalho normal não deve 
exceder oito horas, mas pode ser estendida até dez horas se, nos úl timos três meses, a média de horas trabalhadas tiver sido igual a oito horas diárias. Embora este padrão possa ser modificado por meio de convenção coletiva, a legislação estabelece que a jornada de trabalho semanal não pode ser superior a 48 horas, considerando a média dos últimos 12 meses (ANXO \& KARLSSON, 2019). O flexitime prevê horas-limite durante as quais todos os empregados devem estar presentes na empresa: eles podem trabalhar mais ou menos horas dentro destes limites. As horas extras podem ser acumuladas até certo ponto e compensadas ou pagas. Sistemas eletrônicos de registro de horas e bancos de horas foram criados em empresas para registrar as horas de trabalho realizadas individualmente (EURES, 2019).

No Reino Unido, um trabalhador regular tem jornada de trabalho semanal de 35 horas, sendo que, na ausência de acordo individual ou coletivo que disponha sobre tempo de trabalho diverso, o limite de trabalho semanal é de 48 horas. Neste país, a compensação de horas é conhecida como "time off in lieu", e é utilizada em substituição ao pagamento de horas extras. Se o tempo de trabalho cumprir a carga horária semanal máxima de 48 horas ou aquela que for estabelecida por meio de convenção coletiva ou acordo individual, o banco de horas poderá ser utilizado se negociado entre patrão e empregado (UNITED KINGDOM GOVERNMENT, 2019). No México, as jornadas e seus horários podem ser flexíveis, com autorização para remuneração apenas das horas trabal hadas, não tendo a reforma alterado esta permissão (BIAVASCHI; DROPPA; ALVARENGA; COELHO; PERNIAS, 2017).

Enquanto isso, na Coreia (2017-2018), a jornada semanal máxima foi reduzida de 68 para 52 horas (incluídas as horas extras), e as férias anuais subiram de 10 para 15 dias por ano.

\section{Descanso}

No Brasil, com a reforma, os intervalos para descanso em jornadas de 12 horas trabalhadas para 36 horas de descanso interjornadas (12×36) podem ser indenizados, não mais sendo obrigatório o seu gozo (art. 59-A) para todas as categorias. Além disso, se o empregador deixa de conceder, total ou parcialmente, o intervalo intrajornada, o pagamento terá natureza meramente indenizatória, não mais repercutindo em outras parcelas salariais, e será restrito apenas ao período suprimido. Por fim, o artigo 611-A, inciso III, da CLT autoriza que negociação coletiva reduza o tempo de descanso intrajornada - que anteriormente era de, no mínimo, uma hora para jornadas de trabalho superiores a 6 horas-para o limite mínimo de meia hora.

Na Espanha, a reforma ocorrida em 2012 autoriza que os acordos de empresa prevaleçam sobre acordos setoriais sobre tempo de trabalho, regime de turno de trabal ho e planejamento anual de férias (art. 84, 2, do ET). Estes acordos não podem, entretanto, regulamentar o trabal ho noturno, o descanso semanal, a quantidade de horas anuais, entre outros. O descanso entre duas jornadas de 
trabalho na Espanha é de 12 horas, e para jornadas de trabalho superiores a 6 horas, o intervalo intrajornada é de 15 minutos. Na França, por meio do artigo 4 da Ordonnance n 2017-1386, de 22 de setembro de 2017, instituiu-se que, na ausência de acordo de empresa ou convenção coletiva, o contrato de trabalho pode fixar a remuneração do tempo de pausa (ARAÚJO; DUTRA; JESUS, 2017). O intervalo mínimo intrajornada é de 20 minutos. Na Alemanha, as horas de trabalho e os intervalos são estipulados na Lei de Horas de Trabalho (ArbZG). A jornada semanal é de 38 a 40 horas, ao passo que a jornada diária varia de 8 a 10 horas, e, após seis horas de trabalho, um descanso de 30 minutos é obrigatório - as pausas constam do $\$ 4$ do Act Time Working Act (Arbeitszeitgesetz), que define que, para horas de trabalho entre seis e nove horas, deve haver pelo menos um intervalo de meia hora. Entre dois dias de trabal ho é devido um descanso de 11 horas (EURES, 2019).

No Reino Unido, o intervalo interjornadas é também de 11 horas em geral, e o tempo de pausa é de 20 minutos $^{1}$. No Reino Unido, via de regra, os trabal hadores têm direito a férias remuneradas de 5,6 semanas ou 28 dias de duração. Essa regra também inclui os trabalhadores temporários, os trabal hadores com jornada de trabalho irregular e os trabalhadores intermitentes, sendo que, nesse caso, as férias são calculadas de acordo com o tempo trabalhado. O empregador não é obrigado a remunerar o trabalho em feriados nacionais; assim, o empregador pode descontar os feriados das férias concedidas ao trabalhador. No México, a única previsão constante da reforma ocorrida em 2012, sobre descanso de trabal hadores, diz respeito ao trabalho dos empregados domésticos, como visto acima, que passaram a ter um intervalo entre jornadas de $g$ horas, e intrajornada de 3 horas, caso residam nos locais onde prestam serviços (LÓYZAGA DE LA CUEVA, 2013).

\section{Saúde e segurança}

No Brasil, a reforma trabalhista também flexibilizou o direito à saúde e segurança no ambiente de trabalho em diversos dispositivos, promovendo possível deterioração das condições de trabalho. Destaca-se o artigo 611-A, XII e XIII, da CLT que favorece o negociado sobre o legislado, e autoriza negociações coletivas sobre grau de insalubridade e tempo de trabal ho em locais insalubres. Ademais, trazendo matéria conceitual, o artigo 611-B dita que regras sobre duração do trabalho e intervalos não são consideradas normas de saúde, higiene e segurança do trabalho, contrariando entendimento cristalizado da justiça do trabalho.

O marco regulatório espanhol sobre saúde e segurança ocupacional foi reformulado em 1995, em grande parte devido às pressões sindicais e à necessidade de adaptar a regulamentação espanhola

1 Disponível em https://www.citizensadvice.org.uk/work/rights-at-work/basic-rights-and-contracts/restbreaks-at-work-overview/ acesso em 22.11.2019. 
ao quadro jurídico da União Europeia em matéria de saúde e segurança. As normas de segurança e saúde do trabal ho na Espanha têm força cogente, de forma que a negociação coletiva pode melhorar e complementar a legislação, mas não rebaixar estes níveis de proteção. Mesmo com ampliação dos poderes empresariais nas reformas, permanece com os empregadores o dever de avaliação, antecipação e prevenção de riscos ocupacionais. Renúncias unilaterais aos requisitos mínimos estabelecidos na Lei de Segurança e Saúde Ocupacionais não são permitidas (LINARES \& LOPEZ, 2015). Na França, havia, no âmbito das empresas, juntamente com outros dois comitês, o Comitê de Higiene, Segurança e Condições de Trabalho (CHSCT). Após a reforma trabalhista de 2017, este Comitê foi convertido em um único órgão, chamado de "Comitê Social e Econômico" (CSE), a ser instituído até 01/01/2020. Em seu lugar, uma Comissão de Saúde, Segurança e Condições de Trabalho (CSSCT) deve ser criada no interior do CSE apenas em empresas com mais de 300 funcionários, ou em empresas com quantitativo de 50 a 299 funcionários, desde que tenham, ao menos, uma instalação nuclear ou apresentem riscos de acidentes maiores e certos depósitos de minerais, e, ainda, dependente de autorização dada por um inspetor do trabalho (ARAÚJO; DUTRA; JESUS, 2018). Com exceção destes casos, as demais empresas não mais precisam ter um comitê específico para discutir questões relacionadas à saúde e segurança do trabalhador.

No México, a reforma ocorrida em 2017, previu que os afastamentos por licença médica deixem de pagar remuneração equivalente a 100\% do salário do trabalhador, passando a pagar um percentual de 50\%. Além disso, foi estabelecido que as tabelas de adoecimentos e incapacidades permanentes sejam modificadas por uma comissão consultiva, abrindo a possibilidade para que os empregadores determinem quais agravos sejam suscetíveis de pagamento de licença (ROMERO \& ACEVEDO, 2017). Na Coreia, em 2018, foi aprovada a Lei de Saúde e Segurança Ocupacional, que aumenta a responsabilidade dos empreiteiros contratantes, incrementa punições, aumenta seu âmbito de atuação e permite aos trabal hadores paral isar operações perigosas (SAN, 2019).

Efetividade das normas trabalhistas

\section{Sindicatos}

No Brasil, os sindicatos sofreram fortes ataques por conta da reforma. Sua principal fonte de custeio, a contribuição sindical, deixou de ser obrigatória (arts. 578, 579 e 582 da CLT). Os sindicatos não têm mais a seu favor a obrigatoriedade patronal de homologação das verbas rescisórias para empregados com contrato superior a um ano, fator que impelia os empregadores ao correto pagamento dos créditos decorrentes dos direitos dos trabalhadores. Ainda, as dispensas em massa não mais exigem negociação prévia com os sindicatos, como vinham exigindo os tribunais trabalhistas, enfraquecendoainda mais a atuação sindical (art. 477-A). 
$\mathrm{Na}$ Espanha, as reformas têm priorizado hierarquicamente os acordos de empresa em detrimento dos acordos setoriais (convenções coletivas). Neste país, as convenções coletivas agora vigem por tempo máximo de dois anos (antes tinham duração indefinida). A lei espanhola regula as demissões em massa, que são as mais impactantesquanto à perda de postos de trabalho, e estabelece critérios para caracterizá-las, bem como mantém o procedimento prévio de consulta junto às representações sindicais estabelecido pela lei anterior. Na reforma espanhola, apesar de todas as formulações precarizantes contidas na lei e apesar de também constarem mecanismos de enfraquecimento do poder sindical, o papel desempenhado pelas organizações sindicais foi mantido.

$\mathrm{Na}$ França, em 2008, foi legalizada a rescisão contratual por meio de negociação individual (rupture conventionnelle). Por meio dela, os empregadores e trabalhadores poderiam chegar a um acordo sobre a rescisão do contrato de trabalho, que era válida caso não fosse contestada pelo Ministério do Trabalho (VLANDAS, 2017). A partir de 2012, empresas francesas que estivessem enfrentando dificuldades econômicas foram autorizadas a negociar com os sindicatos um ajuste na remuneração e na jornada de trabalho dos seus empregados, que poderá vigorar por até dois anos (VLANDAS, 2017). Neste país, no entanto, a mudança mais substancial diz respeito à hierarquia ou prevalência das normas jurídicas: tal como se dava no Brasil, neste país também vigorava o princípio da aplicação da norma mais benéfica ao trabalhador; assim, um acordo de empresa, apesar de específico e local, poderia ter mais força normativa do que uma convenção coletiva ou mesmo diante da lei ou Constituição, acaso representasse uma vantagem para o trabalhador. Com as reformas ocorridas em 2016 e 2017 isto mudou, de forma que, atualmente os acordos de empresa - mais localizados e peculiares - tendem a prevalecer sobre a negociação coletiva empreendida pelos sindicatos, ainda que esta última seja mais benéfica ao trabalhador. Foi autorizada, ainda, a negociação direta entre patrões e empregados para empresas com até 11 funcionários, sem a presença de delegados sindicais (ARAÚJO, et al, 2017).

$\mathrm{Na}$ Alemanha, propostas de reformas mais abrangentes dos sindicatos, que visam aumentar a prevalência dos conselhos dos trabalhadores e seus direitos de autodeterminação em relação ao uso de contratos atípicos, até agora têm falhado (JAEHRLING, 2017). Em 2014, a Alemanha adotou um pacote legislativo para "reforço da autonomia de negociação" que incluiu um conjunto de medidas destinadas a reforçar a extensão dos acordos coletivos. Contemplava os seguintes requisitos: aplicável a convenções coletivas já existentes, com cobertura a 50\% de todos os trabalhadores de determinada área de negociação, aprovação por um Comitê de Negociação Coletiva, e a possibilidade de organizações patronais de caráter mais abrangente solicitarem a não aplicabilidade da extensão. Ainda neste país, a Lei sobre a Unidade de Acordo Coletivo ( Tarifeinheitsgesetz ) foi aprovada em 22 de maio de 2015: sob esta nova legislação, se dois acordos coletivos não idênticos de diferentes sindicatos no mesmo estabelecimento entrarem em conflito e, concomitantemente, esta situação 
for contestada por uma das partes negociadoras (empregador) ou sindicato), somente o acordo coletivo do sindicato com o maior número de membros do estabelecimento seráaplicado, diferentemente da regra espanhola e francesa. A corte alemã considerou válida esta alteração legal² .

No Reino Unido, a partir de 1979 foi promovido um desmonte da representação sindical, iniciando-se um processo de individualização do direito do trabal ho baseado na redução do poder de barganha dos sindicatos e de sua influência na regulação do trabalho (HOWELL, 2007); as reformas foram realizadas no sentido de limitar as ações dos sindicatos, redução da estabilidade no emprego concedidas a dirigentes sindicais e incentivando a segmentação dentro dos sindicatos. No México, foram adotadas medidas como obrigatoriedade de estatutos, publicidade, periodicidade de assembleias, prestação de contas, proibição de condutas anti ssindicais (arts. 133, 364 Bis, 365 Bis, 371, e 373 da LFT), além da criação de um novo organismo federal responsável pelo registro sindical.

Em matéria sindical, a maioria dos países pesquisados tem invertido a principiologia típica do direito do trabalho, que confere primazia à legislação mais protetiva, para conferir prevalência aos acordos individuais ou coletivos (setoriais) mais específicosem detrimento das convenções coletivas, mais genéricas.

\section{Acesso à justiça}

O direito ao acesso à justiça tem importância primária para a efetivação e o acesso aos demais direitos individuais e sociais, uma vez que a definição de qualquer direito só faz sentido caso estejam disponíveis mecanismos para sua efetiva reinvindicação (garantias processuais). O discurso hegemônico sustenta que haveria quantidade excessiva de ações trabalhistas e suposta incerteza jurídica, consequências diretas de uma legislação extensa e protetiva, que incentiva os trabalhadores a ajuizarem ações abusivamente.

No Brasil as principais alterações foram as limitações aos efeitos das ações (como a imposição de tetos aos valores indenizatórios), criação de norma impondo pagamento de honorários periciais e de sucumbência (para os advogados da parte contrária) e custas processuais pelo trabalhador em determinadas situações de derrota processual.

$\mathrm{Na}$ Espanha, em caso de desacordo entre as partes, a reforma trabal hista de 2010 estabeleceu um novo procedimento - em substituição à consulta aos trabal hadores -também aplicável aos casos de modificações substanciais das condições de trabal ho da empresa. Este novo procedimento envolve o recurso aos instrumentos de mediação estabelecidos nosacordos ou convenções (art. 41 do ET). Em

2 Disponivel em https://www.etui.org/ReformsWatch/Germany/Germany-Act-on-Collective-AgreementUnity-is-compatible-with-the-constitution acesso em 24.11.2019. 
caso de litígio sobre convenções coletivas, a reforma de 2012 impôs arbitragem obrigatória a um órgão tripartite do ministério do trabalho (CLAUWAERT \& SCHOMANN, 2012).

Na França, houve três mudanças relevantes com as reformas ocorridas em 2017: fixou-se um teto para sanções pecuniárias impostas aos empregadores em caso de não comprovação da causa da demissão no tocante à demissão por justa causa; houve uma redução do prazo prescricional para ingressar com ações em casos de demissão abusiva, passando de 2 anos para 1 ano; porfim, a empresa não é mais obrigada a comprovar os motivos da demissão, como exigia anteriormente o Código do Trabalho (ARAÚJO; DUTRA; JESUS, 2017). Na Alemanha, antes de levar o conflito à Justiça, é feita uma tentativa de conciliação, estimulada pelo juiz de primeiro grau, que expõe às partes informações sobre os riscos que o alongamento da demanda pode gerar: 60\% das ações alemãs contestam as demissões e, quando a Justiça dá ganho de causa ao trabalhador, ele recebe salários retroativos pelo tempo de duração do processo. O empregador, assim, fica mais propenso a uma solução negociada. Por outro lado, a execução do acordo é imediata - o que melhora a disposição do trabalhador a chegar a um consenso, ainda que receba menos do que esperava (WOLFGANG, 2019).

Em 2014 foi estabelecida uma mudança semel hante à reforma legal brasileira no Reino Unido. Reclamantes que quisessem levar casos à justiça do trabal ho deveriam primeiro notificar o $A C A S$, que buscaria a solução do conflito por meio de conciliação. Além disso, no Reino Unido, em 2013 começaram a ser cobradas taxas para o ajuizamento de ações na justiça trabalhista. Até então, o acesso à justiça havia permanecido livre e gratuito. Em julho de 2017, a Supreme Court revogou as taxas judiciais por meio do julgamento do caso $R$ (Unison) $v$ Lord Chancellor, oportunidade em que se declarou serem incompatíveis com os princípios do Common Law quaisquer medidas ou cobranças que impeçam o direito básico do acesso à justiça. De acordo com Pyper e McGuinness (2018), o número de casos pode não ter aumentado nos níveis de 2013 por conta da existência do Acas Early Conciliation. Desde maio de 2014, reclamantes que queiram levar casos à justiça do trabal ho devem primeiro notificar o $A C A S$, que buscará a solução do conflito por meio de conciliação.

No México, da mesma forma como já se deu no Brasil em passado recente, artigos da Constituição Mexicana foram alterados para extinguiras juntas tripartites de conciliação e arbitragem e substituí-las por tribunais trabalhistas, que podem ampliar o prazo e as custas processuais (ROMERO \& ACEVEDO, 2017).

Como se vê, a tônica tem sido de evitar o acesso à justiça e, de alguma forma, pressionar os trabalhadores a uma conciliação em que estes abram mão, ainda que parcialmente, de alguns dos seus direitos e créditos.

A redução da efetividade como elemento central da (re)mercadorização do trabalho nas reformas 
As mudanças legislativas promovidas pelas reformas trabalhistas podem, conforme já discutido, eliminar direitos de forma direta ou indireta. No primeiro caso, são suprimidos direitos antes previstos. Como, por exemplo, a supressão da possibilidade de horas in itinere, direito previamente garantido no artigo 58 da CLT e suprimido pela Reforma de 2017. A eliminação dos direitos também pode ocorrer de forma indireta, ampliando as possibilidades de negociação de direitos, ou fragilizando a efetividade das normas, seja impondo restrições para os trabalhadores acessarem a justiça do trabalho, seja fragilizando a representação dos trabalhadores ou enfraquecendo a fiscalização do trabalho. A efetividade também é fragilizada pela criação de comissões de conciliação prévia, o que ocorre em países como Reino Unido, México, Espanha, e no Brasil em passado recente. No caso do Reino Unido, desde 2014, é obrigatório que haja tentativa de negociação nas comissões de conciliação prévia antes de o trabalhador ajuizar ação na justiça trabalhista. Esse mecanismo faz com que direitos taxativos se tornem objeto de negociação.

Tais mudanças, ainda que não eliminem nenhum direito explicitamente, contribuem para a redução da efetividade da legislação. Sendo assim, mesmo que trabalhadores tenham direitos explicitamente violados, deixam de buscar a justiça por conta da fragilidade da representação e também pelo risco de entrar najustiça contra o empregador.

De maneira abstrata, a efetividade significa a realização do Direito, sua materialização. Para que uma norma seja efetiva, devem se aproximar o preceito legal e a realidade social. Sem o mínimo de eficácia, a norma não passa de mera construção teórica. Sendo assim, ainda que existente, se o direito não tiver respaldo na realidade, limita-se à "letra morta".

A redução da efetividade dos direitos remanescentes pelo poder público.

No Reino Unido, os dados apresentados por Pypere McGuinness (2018) mostram que, entre abril e junho de 2013, período imediatamente anterior ao início da cobrança de taxas judiciais dos trabal hadores que decidissem ajuizar ações, a justiça trabal hista recebia, em média, 13.90o casos por trimestre. Após a entrada em vigor da mudança, essa média caiu para 4.700 novos casos por trimestre. Após a decisão do tribunal superior que considerou a cobrança das taxas judiciais inconstitucional, 0 número de demandas trabalhistas aumentou, alcançando a média de 11.700 novas demandas no trimestre de abril a junho de 2018, embora não tenha sido alcançado o mesmo nível de 2013, quando eram ajuizadas, aproximadamente 14 mil novas ações trimestralmente, provavelmente em decorrência da adoção do ACA. Conforme indicado por Pyper (2018), foram recebidas 289.500 notificações pelo ACAS entre abril de 2014 e junho de 2017, número significativamente superior às 59.200 ações ajuizadas na justiça trabal hista neste mesmo período. Sendo assim, conforme Pyper (2018) indica, o número de notificações feitas para o ACAS é superior ao número de ações ajuizadas 
em 2013, antes da instituição da cobrança de taxas judiciais. Ainda, entre as 92.100 tentativas de conciliação realizadas pelo ACAS em 2016, 16.900 (18\%) foram bem-sucedidas, 17.500 (19\%) seguiram para o tribunal trabal hista e as demais 57.700 (63\%) não foram solucionadas. Desses, alguns acordos podem ter sido realizados informalmente ou o reclamante pode ter desistido da ação (PYPER, 2018). O autor mostra, ainda, dados de questionário proposto pelo ACAS para os reclamantes em 2014, quando ainda eram cobradas taxas para ajuizamento de ação e quando foi instituída a obrigação de recorrer ao ACAS antes de ajuizar ações. De acordo com os resultados, 52\% dos trabal hadores disseram ter procurado a conciliação prévia não apenas por serem obrigados, mas também porque desejavam tentar alcançar um acordo antes de ajuizar ação direto no tribunal, 19\% dos trabal hadores disseram que passaram pela fase de conciliação prévia puramente por obrigação, e, por fim, 24\% buscaram apenas a conciliação prévia, não tendo intenção de ajuizar ação na justiça trabalhista. Neste último grupo, pelo menos $26 \%$ disseram que não tinha intenção iniciar processo trabalhista por conta das custas processuais, muito elevadas.

Como se vê, as reformas estudadas denotam o sentido de restringir o acesso ao poder judiciário, ainda que tais medidas estejam sujeitas a resistências dos próprios tribunais trabalhistas, como se deu no Reino Unido. A restrição do acesso à justiça, a depender do país, pode pe sar mais na regulação do que a mudança de vários itens do direito material, visto que, se a taxa de evasão à norma formal for alta, a efetividade do direito trabal hista será muito baixa.

$\mathrm{Na}$ Espanha, as mudanças promovidas pela reforma trabal hista, ao menos inicialmente, não reduziram de forma substancial a judicialização de conflitos trabalhistas. Embora o número de matérias resolvidas tenha caído de 342.361 ações em 2010 para 333.201 ações em 2011, essa situação não se manteve em 2012, quando foram resolvidas 352.992 matérias, tendo este patamar se mantido relativamente estável até 2015 , quando voltou a cair a quantidade de matérias resolvidas, conforme indicam dados estatísticos disponibilizados pelo Consejo General del Poder Judicial.

No caso da reforma trabal hista brasileira, a nova legislação, além de privilegiar o princípio da autonomia da vontade, criou obstáculos ao acesso à justiça, além limitar a atuação dos juízes e tribunais do trabalho. A lei n. 13.467/2017 determina que o pagamento de honorários periciais, honorários de sucumbência e custas processuais seja realizado pelo trabalhador em determinadas situações.

O risco de ter que pagar as custas processuais parece inibir a busca dos trabalhadores pela efetivação de seus direitos. Essa tendência, apresentada pelo Reino Unido, também parece se concretizar no caso do Brasil, como indicam dados do TST - Tribunal Superior do Trabalho sintetizados no gráfico 1 apresentado abaixo. 
Gráfico 1 - Casos novos recebidos pelas Varas do Trabalho entre janeiro de 2014 e junho de 2019

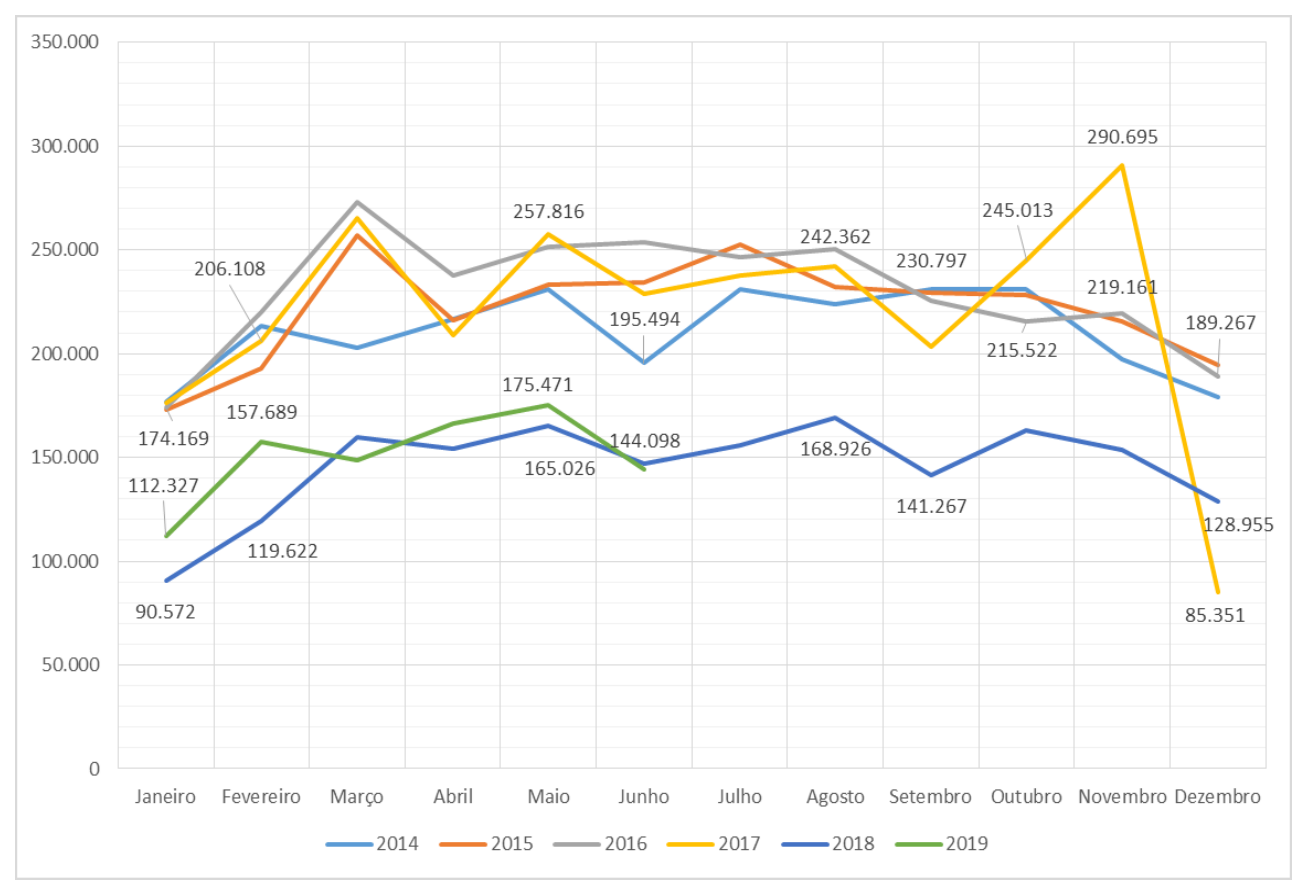

Fonte: Elaboração própria com base em dados do TST

O Gráfico 1 mostra o número de novos casos recebidos pelas varas do trabalho entre $2014 \mathrm{e}$ 2017, de acordo com dados disponibilizados pelo TST. Nota-se que houve um aumento relevante na quantidade de casos novos em novembro de 2017 , e, depois, uma queda brusca a partir de dezembro. Em 2018 e em 2019, o número de casos novos permanece em nível mais baixo do que nos anos precedentes. Segundo os dados apresentados, o número de casos novos recebidos pelas varas do trabal ho caiu 34\% em 2018, em relação à quantidade total de 2017.

Em 2019, o patamar continua distante dos anos anteriores. Entre janeiro e abril de 2019, o número de novas ações aumentou 14\% em relação ao mesmo período do ano anterior, mas, as 597.215 novas ações ajuizadas em 2019 estão consideravelmente abaixo da média de 852.646 novas ações que foram ajuizadas entre janeiroe abril de 2014 a 2017.

Conforme discutido, um dos argumentos em defesa da reforma sustenta que a quantidade de ações najustiça trabal hista brasileira costumava sermuito al ta e a justiça, demasiadamente protetiva. Para avaliar se, pelo menos nocaso do Brasil, a quantidade de processos trabal histas é excessiva, cabe avaliar se o descumprimento da norma trabal hista é equivalente ou desproporcional ao número de ações. Há indicadores, como as notificações de acidentes de trabalho, a arrecadação do FGTS e a informalidade que sugerem o descumprimento generalizado e crescente das normas de proteção ao trabalho no Brasil e que, na verdade, o número de ações é muito menor do que poderia ser.

Em primeiro lugar, de acordo com dados da Procuradoria Geral da Fazenda Nacional (PGFN), eram devidos cerca de 27,6 bilhões ao FGTS em 2017. Neste mesmo ano, o documento do TST de 
assuntos mais recorrentes nas varas do trabal ho quanto a casos novos indica que foram apreciados 317 mil processos pela Justiça do Trabal ho que continham demandas relativas à ausência de depósitos do FGTS, este representando $013^{\circ}$ tema mais recorrente na justiça em 2017 (TST, 2017).

Considerando que, no primeiro trimestre de 2018, por volta de 2,4 milhões de empresas estavam devendo ao FGTS e havia aproximadamente 11,7 empregados formais por empresa de acordo com dados da RAIS (Relação Anual de Informações Sociais do Ministério do Trabalho), é evidente o contingente relevante de trabal hadores com FGTS sonegado (FILGUEIRAS, 2018). Porém, o número de pedidos novos apreciados pelas varas do trabal ho referentes ao depósito do FGTS caiu para 186 mil em 2018, o que representa uma queda de 41\% do número de pedidos em relação ao ano anterior. Não há indicações da redução do nível de sonegação do FGTS. Pelo contrário, dados da Fiscalização do Trabalho mostram que em 2018 foram notificados cerca de 4,8 bilhões em 2018, aproximadamente $20 \%$ a mais do que em 2017. Mais uma vez, em 2019 a situação não parece ter melhorado. Entre janeiro e abril de 2019, a notificação foi $36 \%$ maior do que no mesmo período do ano anterior.

A seguir, cumpre avaliar a situação dos acidentes de trabalho. De acordo com a legislação vigente, a empresa é obrigada a notificar a previdência social em caso de acidente de trabal ho através da emissão de uma CAT (Comunicação de Acidente de Trabalho). A literatura é unanime ao identificar que há subnotificação de acidentes de trabalho no Brasil. Filgueiras e Carvalho (2017) apresentam dados da Pesquisa Nacional de Saúde realizada pelo Instituto Brasileiro de Geografia e Estatística (IBGE) em 2013 que indicam que, por volta de 4,9 milhões de pessoas com mais de 18 anos sofreram acidentes de trabalho naquele ano, sendo que apenas $700 \mathrm{mil}$ foram registrados pelo INSS (FILGUEIRAS; CARVALHO, 2017).

Por sua vez, dados disponibilizados pelo TST (2017) indicam que foram apreciados pela justiça do trabalho 252.686 pedidos relacionados a acidentes de trabalho neste mesmo ano. Para alcançar este número, foram considerados os pedidos de novas ações relativos a acidentes de trabalho e doença ocupacional referentes a dano moral, material e à estabilidade acidentária. Os itens podem aparecer em mais de um processo, por isso, na verdade, são bem menos do que 252 mil processos. Além disso, quando se considera a estatística do IBGE que indica que o número de acidentes é sete vezes maior do que as notificações, percebe-se que esta parcela representa pouco mais da metade do número de ações que poderiam de fato ter ocorrido.

Em 2018, a situação se agrava. O percentual de acidentes sem CAT emitida é o maior desde 2012. Em contraste, dados do TST (2018) mostram que foram apreciados por volta de 109.256 pedidos sobre acidentes de trabalho e doença ocupacional, somando-se os relativos a dano moral, dano material e estabilidade acidentária. Este número representa queda de quase $57 \%$ no número de pedidos em relação ao ano anterior. 
Indicadores de informalidade também demonstram descumprimento crescente da legislação trabalhista pelo patronato, ao mesmo tempo em que cai o número de ações na justiça com esse tipo de pedido.

Em 2017 constavam 162.335 pedidos em novas ações ajuizadas que solicitavam o reconhecimento do vínculo de emprego (TST, 2017). Para alcançar este número, foram somados os novos pedidos relativos a reconhecimento de relação de emprego e o reconhecimento de relação de emprego em atividades específicas (cooperativa de trabalho, trabalho em condições análogas à de escravo, etc.). Esse número representa apenas uma pequena parcela das mais de 11 milhões de pessoas que estavam em um vínculo de emprego, sem ter, no entanto, a carteira assinada de forma explícita no último trimestre de 2017, de acordo com dados do IBGE. Vale ressaltar, ainda, que as ações geralmente contêm mais de um pedido. Sendo assim, considerando que estes números representam o número de pedidos, mas não de ações, é certo que existem muito menos ações solicitando o reconhecimento de vínculo.

Conforme dados da PNAD, mesmo que se considere apenas trabalhadores que possuem vínculos de emprego ativos explicitamente sem carteira assinada e que, indiscutivelmente, têm direitos subtraídos, o contingente de informais tem batido recordes desde a reforma de 2017 (no final de 2019 eram mais de 12 milhões). Contudo, em 2018, dados do TST (2018) mostram que foram apreciadas por volta de 108.094 ações solicitando o reconhecimento de vínculo empregatício, uma redução de $33 \%$ em relação ao ano anterior.

Sem considerar os trabalhadores cuja pretensão ainda não prescreveu, os dados apresentados indicam que muitos trabalhadores, ainda que tivessem direito a propor a ação, não o fizeram. Assim, mais uma vez, o número efetivo de litígios em relação ao número potencial, que já era baixo antes da reforma, tende a cair ainda mais.

Em todos os casos apresentados, o número de ações ajuizadas é consideravelmente baixo, em relação ao que efetivamente poderia ser, mesmo antes da reforma. Contraditoriamente, a ilegalidade se agrava após a reforma, mas o número de ações cai fortemente. Assim, as mudanças promovidas pela reforma trabal hista brasileira que aumentam a restrição ao acesso à justiça já estão gerando impactos significativos. Os trabalhadores que já buscavam pouco a justiça, tendem a procurá-la menos ainda. Sendo assim, a reforma trabalhista, ao afetar a efetividade dos direitos ainda existentes, pode provocar efeitos mais profundos do que inúmeras modificações no direito material .

\section{Considerações finais}

O discurso a favor da reforma trabalhista tem ganhado força nos últimos anos. A firma-se que a flexibilização do direito do trabalho é imperiosa, representando a solução para mercados de 
trabalho informais e com elevados índices de desemprego. A adoção de mudanças legislativas restritivas de direitos compõe tendência geral do capitalismo global; embora se considere as particularidades de cada região, quase todos s países pesquisados reduziram a proteção ao trabalho.

O texto buscou apresentar e debater o conteúdo e as consequências da implementação das chamadas Reformas Trabal histas ao redor do mundo a partir da análise da experiência de sete países. Dando ênfase ao caso brasileiro, o texto apresentou algumas mudanças legislativas na Espanha, França, México, Reino Unido, Alemanha e Coreia. As reformas reduzem direitos dos trabalhadores nos diversos aspectos da relação de emprego, que vão da contratação à saúde e segurança.

Por si só, as reformas trabalhistas (re)mercadorizam o trabalho ao associar a retirada de direitos trabal histas ao aumento do poder de mando dos empregadores, ampliando o seu controle sobre a força de trabalho. Mas, além disso, reformas trabalhistas promovem uma mercadorização mais implícita e sutil, via redução da efetividade dos direitos remanescentes.

No caso da reforma trabalhista brasileira, um dos principais impactos é sobre o acesso à justiça do trabalho. A nova lei descaracteriza o instituto da justiça gratuita e cria o sistema de sucumbências recíprocas em causas trabalhistas. Este tipo de restrição tende a promover impactos mais relevantes do que a modificação de inúmeros dispositivos do direito material.

Há uma redução substancial no número de ajuizamento de ações após a entrada em vigor da reforma trabalhista. Embora se trate de mudança legislativa muito recente, a dinâmica do mercado de trabalho brasileiro e os dados sobre os assuntos mais recorrentes nas demandas apreciadas pela Justiça do Trabalho indicam que, ao contrário do que o discurso hegemônico pressupõe, o suposto excesso de demandas trabalhistas decorre não da rigidez normativa, mas sim, do descumprimento sistemático às normas de regulação e proteção do trabalho.

O padrão de gestão da força de trabalho no Brasil se baseia, historicamente, na tentativa generalizada de eliminação dos custos do trabalho, expressando-se, entre outros, na informalidade/ilegalidade no mercado de trabalho. Para o empregador, o risco de sofrer sanções é reduzido. A reforma trabalhista, ao afastar os trabalhadores da justiça do trabalho, incentiva o descumprimento da legislação implicandona baixa efetividade dos direitos ainda existentes.

\section{Referências}

ALONSO, A. V. El trabajo autonómo en España: evolución, concepto y regulación. Revista del Ministerio de Trabajoy Asuntos Sociales, 13-44, 2000.

ANXO, D.; KARLSSON, M. Overtime work: a review of literature and initial empiral analysis. Geneva: ILO, 2019.

ARAÚJO, M. A.; DUTRA, R. Q.; JESUS, S. C. Neoliberalismo e Flexibilização da Legislação Trabal hista. Revista Eletrônica do Curso de Direito, UNIFACS, 2018. 
ARAÚJO, M.; DUTRA; R.; JESUS, S. Neoliberalismo e Flexibilização da Legislação Trabal hista no Brasil e na França. Cadernos do CEAS, 558-581, 2017.

BARROS, C. M. A Terceirização e a Possibilidade de Regulamentação (PL 1621/2007). Disponível em: https://www.conjur.com.br/dl/terceirizacao-cedes.pdf Acesso em: 14 de Abril de 2019

BIAVASCHI, M.; DROPPA, A.; ALVARENGA, A. P.; COELHO, E. D.; PERNIAS, T. R.). Subsídios para a discussão sobre a reforma trabalhista no Brasil - Experiências Internacionais - Parte 02. Disponível em: http://www.reformadaclt.com.br/wp-content/uploads/2017/12/Texto-deDiscussa\%CC\%830-2-Os-impactos-de-algumas-reformas-trabalhistas-naregulac\%CC\%A7a\%CC\%830-e-nas-instituic\%CC\%A70\%CC\%83es-pu\%CC\%81blicas.pdf Acesso em: $13 / 04 / 2019$.

BRUTTEL, O.; BAUMANN, A.; DUTSCH, M. The new German statutory minimum wage in comparative perspective: employment effects and other adjustment channels. European Journal of Industrial Relations, 145-162, 2017.

BUSTILLO, R. M.; ESTEVE, F. The neverending story. Labour market deregulation and the performance of the Spain labour market. In: A. PIASNA; M. MYANT. Myths of employment deregulation: how it neither creates jobs nor reduces labour market segmentation. Brussels: ETUI, 2017, pp. 61-80.

CAÑADA, E. Reforma Trabal hista e Terceirização na Espanha: a Precarização do Trabalho das Camareiras. Revista do Centro de Pesquisa e Formação. São Paulo, 55-70, 2018.

CLASEN, J.; CLEGG, D.; KVIST, J. European Labour Market Policies. Crisis. ETUI Working Paper, $18 / 12 / / 2012$.

CLAUWAERT, S.; SCHOMANN, I. The crisis and national labour law reforms: a mapping exercise. Brussels: ETUI, 2012.

CNI. Competitividade e crescimento: a agenda da indústria. Brasília: CNI, 1998.

CNI. A indústria e o Brasil: uma agenda para crescer mais e melhor. Brasília: CNI, 2010.

CNI. 101 propostas para modernização trabalhista. Brasília: CNI, 2012.

COLNAGO, L. D. Trabalho Intermitente - Trabalho "zero hora" - Trabal ho fixo descontínuo. Revista Ltr: legislação do trabalho, São Paulo, SP, v. 82, n. 1, p. 38-46, jan. 2018.

CONFEDERACIÓN SINDICAL DE COMISIONES OBRERAS. Efectos de la reforma laboral. 2013. Disponível em: https://www.ccoo.es/bffd0794276of1 $151 \mathrm{e} 6438 \mathrm{e} 745 \mathrm{df} 2 \mathrm{e} 3$ foo0001.pdf Acesso em: 10/10/2019

CONFEDERACIÓNSINDICAL DE COMISIONES OBRERAS. Comparativa Reforma Laboral. Universidade Pablo de Olavide Sevilha, 2019. Disponível em: https://www.upo.es/ccoo/PDI/comparativa reforma laboral.pdf Acesso em: 13/04/2019.

COWLING, M.; MITCHELL, P. The evolution of UK self-employment: a study of government policy and the role of the macroeconomy. The Manchester School Vol LXV n. 4, p. 427-442, 1997. 
D'AMORIM, M. C. O contrato de trabalho intermitente. (Trabalho de Conclusão de Curso), Universidade Federal da Bahia, 2018. Disponível em:

https://repositorio.ufba.br/ri/bitstream/ri/26304/1/Mariana\%20Correia\%20D\%27Amorim.pdf Acesso em: 09/10/2019.

DA SILVA, H. B. Comentários à Reforma Trabalhista - Análise da Lei 13·467/2017. São Paulo: Editora Revista dos Tribunais, 2017.

DE LA GARZA, E. Antiguas e nuevas formas de subcontratácion. In: Relaciones Triangulares de Trabajo ¿Fin de la estabilidad laboral ¿. México, Fundação Friedrich Ebert, 2005.

EHMKE, E.; LINDNER, F. Labour market measures in Germany 2008-13. Geneva: ILO, 2015.

EICHHORST, W.;MARX, P. Reforming German labour market institutions: A dual path to flexibility. Journal of European Social Policy, Volume 21, Edição 1, 73-87, 2011.

EMBAIXADA DO BRASIL EM SEUL. Relações de Trabalho na Coreia - orientações para cidadãos brasileiros. Disponível em: http://www.brasileirosnomundo.itamaraty.gov.br/cartilhas/orientacoespara-o-trabalho-no-exterior/cartilha-brasemb-seul-relacoes-de-trabalho-nacoreia-1.pdfAcesso em: 15/04/2019.

EURES. The European Job Mobility Portal. Living and Working Conditions. Disponível em: https://ec.europa.eu/eures/main.jsp?catld=8402\&acro=living\&lang=en\&parentld=7778\&countryld=D E\&living= Acesso em: 14/04/2019.

FILGUEIRAS, V. A. Estado e direito do trabalho no Brasil: regulado emprego entre 1998 e 2008. Tese (Doutorado em Ciências Sociais) - FFCH/UFBA. Salvador, 2012.

FILGUEIRAS, V. A.; LIMA, U. M.; FONSECA, I. F. Os Impactos Jurídicos, Econômicos e Sociais das Reformas Trabalhistas. Caderno CRH, v. 32, n. 86, 231-252, 2019.

FORDE, C.; SLATER, G. Labour market regulation and the 'competition state': an analysis of the implementation of the Agency Working Regulations in the UK. Work, employment and society, $590-606,2016$.

GALVÃO, A. Neoliberalismo e reforma trabalhista no Brasil. (Tese de Doutorado). Campinas, São Paulo: Universidade Estadual de Campinas, 2003.

GRIMSHAW, D.; JOHNSON, M., KELZER, A.; RUBERY, J. The governance of employment protection in the UK: how the state and employers are undermining decent standards. In: M. MYANT; A. PIASNA. Myths of employment deregulation: how it neither creates jobs nor reduceslabour market segmentation (pp. 7-21). Brussels: ETUI, p. 7-21, 2017.

GUIMARÃES, A. Q.; BARBOSA, F. C., COSTA, G. O.; NATALINO, E. O. Alemanha: o modelo de capitalismo e os desafios no limiar do século XXI. Revista de Sociologia e Política, vol.22, n.51, pp.55-75 2014.

HONG-GEUN, C. Tripartite Agreement on Structural Reforms of the Labor Market and Prospects for the Labor Regime. Economic and Social Development Commission Republic of KoreaAcademic Papers Series, 1-11, Korea, Setembro de 2015.

HOWELL, C. Trade Unions and the State. Princeton: Princeton University Press, 2007. 
ILO. Non-standard employment around the world: Understanding challenges, shaping prospects. Geneva: ILO, 2016.Disponível em:

https://www.ilo.org/wcmsp5/groups/public/@dgreports/@dcomm/@publ/documents/publication/ wcms 534326.pdfAcesso em: 16/04/2019.

JAEHRLING, K. The atypical and gendered 'employment miracle' in Germany: a result of employment protection reforms or long term structural changes? In: A. Piasna; M. Myant, Myths of employment deregulation: how it neither creates jobs nor reduces labour market segmentation. Bruxelas: ETUI, 2017.

KREIN, J. D. Tendências recentes nas relações de emprego no Brasil : 1990-2005. Campinas: Unicamp, 2007.

LEE, J. The labor market in South Korea, 2000-2016. Disponível em:

https://wol.iza.org/uploads/articles/405/pdfs/the-labor-market-in-south-korea.pdf Acesso em: 15/04/2019.

LEE, S.-H., \& MAY, T. (6 de agosto de 2018). Nova lei limita a semana de trabalho a 52 horas na Coreia do Sul. Disponível em: https://exame.abril.com.br/carreira/lei-limita-a-semana-de-trabalhoa-52-horas-na-coreia-do-sul/Acesso em: 10/10/2019.

LINARES, P. J.; LOPEZ, V. Collective Bargain and Occupational Health in Spain. Revista Ciências do Trabalho, 35-44, 2015.

LLOPIS, J. B.; ANDREU, A. R. Pobreza Laboral en España: causas y alternativas políticas. In:Anuario IET de Trabajo y Relaciones Laborales. Desigualdades en el Mercado de Trabajo después de la Gran Recesión, 135-149, 2017.

LÓYZAGA DE LA CUEVA, O. F. Los grandes retrocesos de la reforma laboral. El Cotidiano, 178, 4551, marzo-abril 2013.

MARCELINO, P. R.. Universidade Estadual de Londrina. Dispoível em: UEL:

http://www.vel.br/grupo-pesquisa/gepal/segundosimposio/paulareginapereiramarcelino.pdfAcesso em: 11 de abril de 2016.

MINISTÈRE DUTRAVAIL. (). Les heures supplémentaires : définition et limites. Disponível em: https://travail-emploi.gouv.fr/droit-du-travail/la-remuneration/article/les-heures-supplementairesdefinition-et-limites Acesso em: 02/04/2019.

MINISTÈRIE DU TRAVAIL. (15 de Abril de 2019). Le SMIC. Dsiponível em: https://travailemploi.gouv.fr/droit-du-travail/la-remuneration/article/le-smic-374531, Acesso em: 12/10/2019.

MINISTERIO DE TRABAJO, MIGRACIONES Y SEGURIDAD SOCIAL.. La reforma laboral de 2012. Dsiponívelem:

http://www.mitramiss.gob.es/es/sec trabajo/ccncc/descargas/XXV JornadasNegociacionColectiva 2012 CCNCC Ponencias.pdfAcesso em: (13 de abril de 2019).

MINISTERIO DEL TRABAJO, MIGRACIONES Y SEGURIDAD SOCIAL.. La Reciente Reforma Laboral: Objetivos, Contenido y Análisis. Disponívelem: http://www.mitramiss.gob.es/es/sec trabajo/ccncc/B Actuaciones/Boletin/Boletin-21-adenda.pdf Acesso em: 13 de Abril de 2019. 
NEAL, A. C. XVth Meeting of European Labour Court Judges - United Kingdom. Bundesarbeitsgericht, 54-63, Erfurt, Germany, 2007.

OSHA.. National Focal Points - Germany. Disponível em: https://osha.europa.eu/pt/about-euosha/national-focal-points/germany Acesso em: 14 de Abril de 2019.

PARK, F., PARK; Y.-b., BETCHERMAN, G.; DAR, A. Labor Market Reforms in Korea: Policy Options for the Future. Youngdungpogu, Seoul, World Bank and Korea Labor Institute , 1-418, 2001.

POLANYI, K. A grande transformação: as origens de nossa época. Lisboa: Edições 70, 2012.

PYPER, D.; MCGUINNESS, F. Employment tribunals after R(Unison) vLord Chancellor. London, House of Commons Library, 2018.

QUAGLIA, D.. Plano Hartz -A reforma trabalhista da Alemanha. Disponível em: https://www.linkedin.com/pulse/plano-hartz-reforma-trabalhista-da-alemanha-daniela-quaglia-2 Acesso em: 14 de abril de 2019.

RIGOLETTO, T., \& PAÉZ, C. S. As Experiências Intemacionais de Flexibilização das Leis Trabal histas. Em: J. D. KREIN; D. M. GIMENEZ; A. L. DOS SANTOS, Dimensões Críticas da Reforma Trabalhista. Campinas: Curt Nimuendajú, p.302, 2018.

RODRIGUEZ, A. E. El Trabajo Autónomo: un análisis comparado de Italia y España. Revista Internacional y Comparada de Relaciones Laborales y Derecho del Empleo, Volume 4, Número2, p.p1-24, 2016.

ROMERO, L. Q.; ACEVEDO, B. E. La Reforma Laboral en México y sus Efectos Económicos. Rev. TST, 83, 160-177, Brasília, jul/set, 2017.

ROMITA, A. S. A reforma trabal hista espanhola de 2010. Revista Fórum Trabalhista, 31-41, Belo Horizonte, 2013.

SAN, Y. South Korea: Death of Young Worker Galvanizes a New Movement. 02/01/2019. Disponível em: https://www.labornotes.org/blogs/2019/01/southkorea-death-young-worker-galvanizes-newmovement acesso em 03.08.2019.

THEODOROPOULOU, S. Drifting into labour market insecurity? Labour market reforms in Europe after 2010. Brussels: ETUI, 2018.

UNITED KINGDOM GOVERNMENT.. Health and Safety Reform. Disponível em: HSE:

http://www.hse.gov.uk/aboutus/health-and-safety-reform/lofstedt-progress-report-feb1z.htm Acesso em: (15 de Abril de 2019).

UNITED KINGDOM GOVERNMENT. Holiday Entitlement Rights. Disponível em: https://www.gov.uk/holiday-entitlement-rights Acesso em: (15 de abril de 2019).

UNITED KINGDOM GOVERNMENT.. Maximum Weekly Working Hours. Dsiponível em: https://www.gov.uk/maximum-weekly-working-hours Acesso em: (15 de abril de 2019).

UNITED KINGDOM GOVERNMENT. Overtime Your Rights. Disponível em: https://www.gov.uk/overtime-your-rights Acessoem: (15 de abril de 2019). 
UNITED KINGDOM GOVERNMENT. Time Off And Paid Leave. FontDisponível em: https://www.gov.uk/overtime-your-rights/time-off-and-paid-leave Acesso em: (15 de abril de 2019). VALVERDE, A. M., R, S. B.;L, L. M. XVth Meeting of European Labour Court Judges.

Bundesarbeitsgericht, 46-51, Erfurt, Germany, 2007.

VANDAELE, K.; LESCHKE, J. Following the 'organising model' of British unions? Organising nonstandard workers in Germany and the Netherlands. Brussels: ETUI, 2010.

VLANDAS, T. Labour market performance and deregulation in France during and after the crisis. Em: A. PIASNA; M. MARTIN. Myths of employment deregulation: how it neithercreates jobs nor reduces labour market segmentation. Brussels: ETUI, p. 185-205, 2017.

WOLFGANG, D.. Especialista conversa no TST sobre relações de trabalho na Alemanha (2009). Disponível em https://tst.jusbrasil.com.br/noticias/955014/especialista-conversa-no-tst-sobrerelacoes-de-trabalho-na-alemanha. Acesso em: 30 de Abril de 2019.

\section{Dados dos autores}

Vitor Araújo Filgueiras

Pós-Doutorado em Economia (Universidade Estadual de Campinas - UNICAMP). E-mail: fvitor@ufba.br Ilan Fonseca de Souza

Mestrado em Direito (Universidade Católica de Brasília). E-mail: ilan.fonseca@gmail.com

Gabriela de Freitas Oliveira

Graduação em Economia (Universidade Federal da Bahia). E-mail: gabrielafoliveira1g@gmail.com 